Borka Malčić*,

UDK: $371.212: 378.147$

Nataša Tančić,

DOI: $10.19090 / \mathrm{gff} .2017 .2 .259-273$

Svetlana Kostović,

Originalni naučni rad

Filozofski fakultet

Univerzitet u Novom Sadu

\title{
DIMENZIJE ULOGE NASTAVNIKA U VISOKOŠKOLSKOJ NASTAVI IZ PERSPEKTIVE STUDENATA**
}

Rad je usmeren na analizu i istraživanje evaluativnog aspekta visokoškolske nastave i uloge nastavnika kroz percepciju studenata. U teoriji savremene nastave značajno se menja i uloga nastavnika. Posebno u paradigmi učenja (,učeće društvo“), uloga nastavnika se pomera na preparativnu fazu nastave, a u neposrednoj realizaciji nastave uloga nastavnika postaje saradnička, partnerska i mentorska u strukuiranju nastavnih aktivnosti, čiji su glavni akteri studenti. Svoju subjekatsku poziciju u nastavi, studenti dokazuju i u procesu evaluacije nastave i nastavnika. U radu se prikazuju rezultati mikropedagoškog istraživanja realizovanog na uzorku studenata treće godine Filozofskog fakulteta u Novom Sadu. U istraživanju je primenjen instrument za evaluaciju univerzitetskih nastavnika u izvođenju nastave. Analiza rezultata je pokazala jednofaktorsko rešenje upitnika. Akademski uspeh studenata ne ostvaruje značajnu pozitivnu korelaciju sa percipiranjem kvaliteta nastave i postoji značajna razlika u evaluaciji nastavnog procesa univerzitetskih nastavnika od strane studenata u odnosu na pol ispitanika. Studentska evaluacija je neophodna, ali i nedovoljna za višedimenzionalni konstrukt evaluacije nastavnog procesa univerzitetskih nastavnika. Koncept savremene pedagoške evaluacije, kako pokazuju i rezultati ovog istraživanja, mora uključiti sve elemente evaluacije visokoškolske nastave, pre svega samoevaluaciju nastavnika.

Ključne reči: studenti, univerzitet, evaluacija, nastavni proces,uloga nastavnika.

\section{UVOD}

Prvi podaci o evaluaciji nastavnika u okviru visokog obrazovanja vezuju se za 1970.godinu. Sve do 1990. godine evaluacije su rađene isključivo iz administrativnih razloga, dok je unapređenje rada bilo u drugom planu. Od 1999. godine sa početkom Bolonjskog procesa i političkim usaglašavanjem 48 zemalja,

\footnotetext{
*borka.malcic@ff.uns.ac.rs

** Rad je nastao kao rezultat istraživanja u okviru projekta: Kvalitet obrazovnog sistema Srbije u evropskoj perspektivi koji finansira Ministarstvo prosvete, nauke i tehnološkog razvoja Republike Srbije OI-179010
} 
uspostavljena je harmonizacija različitih univerzitetskih sistema. Korak po korak, implementirane su reforme kako bi se kreirao jedinstven standard rada i kvaliteta fakulteta. Evropski prostor visokog obrazovanja (The European Higher Education Area, EHEA) u cilju unapređenja kvaliteta, zahteva eksternu i internu evaluaciju, kako bi sprovodio pedagoške i organizacione promene.

U savremenom društvu, širom sveta, procesi internacionalizacije i globalizacije su uticali da se u okviru visokog obrazovanja načini konkurentno i otvoreno tržište (Sporn, 2003), gde je primarni cilj univerziteta zadovoljstvo studenata i trka za što boljim rangom u velikoj konkurenciji dostupnih univerziteta. $\mathrm{U}$ tom svetlu, postaje sve bitnije mišljenje studenata, njihovo zadovoljstvo nastavnicima i nastavom, a ono se povezuje i sa potražnjom određenog fakulteta, zadržavanjem na odabranom fakultetu, kao i akademskim uspehom studenata (Helgesen, \& Nesset, 2007). Stoga je kvalitetna evaluacija uslov kvalitetnog obrazovanja i jedan od šesnaest indikatora kvaliteta obrazovanja u Evropskoj Uniji (Đermanov, 2005).

U savremenoj koncepciji nastave, nastavnik podstiče i usmerava autonomno i samostalno sticanje znanja. On postaje pomagač i saradnik, pomaže studentima da dožive uspeh u učenju i podstiče njihovo samopoštovanje (Đukić, 2010). Studenti su sada glavni akteri nastavnog procesa, stavljaju se u centar nastavnog procesa, naglašava se važnost njihovih potreba, a samim tim raste $\mathrm{i}$ značaj njihovog mišljenja o nastavnicima. Modernizacijom nastavnog procesa, prevaziđeno je shvatanje kojim se ocenjivanje svodi samo na nastavnikovo ocenjivanje studenata (Đukić, 2002a). Ono postaje složeni sistem uzajamnog ocenjivanja nastavnika i studenata, koji podrazumeva: nastavnikovo ocenjivanje sopstvenog rada, nastavnikovo ocenjivanje studenata, kao i procene studenata $o$ sopstvenim aktivnostima i njihovo ocenjivanje nastavnika.

Evaluacija visokog obrazovanja se najčešće realizuje na nivou programa i univerziteta, pri čemu se koriste unutrašnje i spoljašnje forme evaluacije (Đukić, 2002a). Danas, u svetu, a i kod nas, rezultati različitih studentskih evaluacija se koriste u proceni kvaliteta samog nastavnika i utiču na njegovo unapređenje (Kuzmanović-Savić-Andrić Gušavac-Makajić Nikolić, \& Panić, 2013). Postoje različite metodološke procedure za procenu kvaliteta i evaluaciju nastavnog procesa univerzitetskih nastavnika. Najčešće korišćena tehnika u evaluaciji nastavnika i nastavnog procesa je studentska procena i ona ima široku primenu kao indikator kvaliteta visokog obrazovanja (Lukas-Santiago-Etxeberria, \& Lizasoain, 2014). Evaluacije ovakvog tipa služe kao važna povratna informacija samim nastavnicima, odsecima, fakultetima, univerzitetima, vladi i istraživačima. 


\section{TEORIJSKI OKVIR RADA}

\section{Studentska evaluacija nastavnog procesa}

Koncept savremene pedagoške evaluacije izrastao je iz vrednovanja koje se u početku oslanjalo isključivo na subjektivno procenjivanje znanja učenika, da bi sredinom XX veka došlo do strukturalnog proširenja koncepcije evaluacije i na druge aspekte vaspitno-obrazovne delatnosti (Đermanov, 2003). Ne postoji opšteprihvaćena definicija evaluacije. Autorka Đukić (Đukić, 2006/2007:108), smatra da: „Evaluacija podrazumeva sistematičnu, kritičku analizu i praćenje kvaliteta u obrazovanju, s ciljem da se obezbedi mogućnost pravovremenog i što delotvornijeg uticanja na obrazovni proces, kako bi se postigla njegova optimalna efikasnost, efektivnost i visok kvalitet".

Studentska evaluacija nastavnog procesa postoji u praksi i koristi se na univerzitetima više od 70 godina. Ona predstavlja jedan od elemenata evaluacije visokoškolske nastave, koja treba da se ostvaruje kroz sistem samoevaluacije i uzajamne evaluacije aktera nastave, nastavnika i studenta (Đukić, 2002b).

Potpisivanjem Bolonjske deklaracije (posle 1999.godine), raste konkurentsko okruženje među fakultetima u Evropi, koji se takmiče za regrutovanje studenata i sve više ih posmatraju kao „kupce“ znanja, čije zadovoljstvo uslugom je na prvom mestu. Time se nastavni proces stavlja pod lupu i njegova efikasnost izbija u prvi plan. Efikasna nastava predstavlja hipotetički konstrukt za koju ne postoji samo jedan indikator (Marsh, 2007). Iz ovoga proizilazi i višedimenzionalni koncept studentske evaluacije nastavnog procesa.

Studentsku evaluaciju nastavnog procesa čine upitnici konstruisani da omoguće studentima kvantitativnu procenu njegovog kvaliteta. One se organizuje sa ciljem: poboljšanja nastavne efikasnosti; za formulisanje kadrovskih odluka, u smislu promocije, mandata, izbora u zvanja, nagrada i sl. i kao informacija koju studenti koriste u svrhu izbora predmeta (Kuzmanović i dr., 2013). Prvobitno cilj evaluacije nastave na fakultetima bio je isključivo formativan i sadržao je povratne informacije o percepciji studenata, sa ciljem promene i unapređenja onoga što se pokazalo neodgovarajuće (Đukić, 2002a). Sa misijom unapređenja kvaliteta u visokom obrazovanju od strane Evropske Asocijacije (European Association for Quality Assurance in Higher Education (ENQA)), različite institucije, teoretičari i praktičari u ovoj oblasti sprovode brojna istraživanja i monitoringe. Berk (Berk, 2005) navodi 12 vrsta evaluacije kada je nastavni proces u pitanju: studentska evaluacija; evaluacija od strane kolega nastavnika; samovrednovanje; video zapisi; intervjui sa studentima; rangiranje od strane alumnija; rangiranje od strane 
zaposlenih na fakultetu; rangiranje od strane pojedinačnog odseka kome nastavnik pripada; rangiranje od strane odgovornih za projekte u kojima nastavnik učestvuje; nagrade koje nastavnik dobija; ishodi učenja i portfolio nastavnika za predmet koji predaje.

\section{Dimenzije evaluacije nastavnog procesa}

Kvalitet nastave je kompleksan fenomen, oko čije dimenzionalnosti postoje oprečna mišljenja. Dok jedni smatraju da je kvalitet nastave jednodimenzionalnog svojstva, drugi navode da je multidimenzionalan, često sa odgovarajućim protivrečnim dimenzijama (Đukić, 2002a). Dimenzije studentske evaluacije nastavnog procesa odnose se na određen broj indikatora ili komponenti koji se koriste $\mathrm{u}$ istraživanju studentske percepcije, nastali $\mathrm{u}$ odnosu na određene kriterijume (Gursoy, \& Umbreit, 2005).

Različiti fakulteti koriste različite modele i instrumente za evaluaciju nastavnog procesa. U praksi postoji veliki broj istraživača koji se bave ovom oblašću u visokom obrazovanju. Feldman (Feldman, 1976) navodi tri dimenzije koje je identifikovao kroz analizu istraživanja i to su: nastava; olakšavanje samog procesa učenja i definisanje predmeta. Isti autor, 1988. godine (Feldman, 1988), u svojoj studiji određuje «dobru nastavu» kroz 22 dimenzije. Istraživači u SAD (Jackson-Teal-Raines, \& Nansel, 1999) su 1999.godine identifikovali šest dimenzija kvalitetnog nastavnog procesa i dve sporedne. Primarne dimenzije u evaluaciji nastavnog procesa univerzitetskih nastavnika bile su: izveštaji studenata; važnost samog predmeta; organizacija nastave; pravičnost prilikom ocenjivanja; teškoće tokom samog semestra i obim predmeta. Dok su se kao sekundarne dimenzije izdvojile: opšti kvalitet same nastave i zahtevi nastavnika vezani za predmet. Iste godine Džonston je realizovao istraživanje (Johnston, \& Reid, 1999), u kom se pošlo od preko 400 konstrukata o dobroj nastavi, koji su svedeni na dvadeset, a oni potom na sledećih šest dimenzija: pristupačnost nastavnika, jasnost u predavanjima, dubina ideja i upitno radoznali stav nastavnika, interakcija sa studentima, interesantna prezentacija nastavnih sadržaja, lična organizovanost i organizovanost nastave. Marks (Marks, 2000), navodi pet dimenzija evaluacije nastavnog procesa: organizaciju nastave; teškoće sa kojima se nastavnici susreću; očekivanja i pravično ocenjivanje; brigu nastavnika za studente i znanja koja studenti treba da steknu.

S obzirom na postojanje ovolikog broja različitih klasifikacija dimenzija evaluacije nastavnog procesa, uviđamo da je uloga nastavnika kompleksna i veoma zahtevna. Zato je neophodno da nastavnici poseduju i unapređuju: teorijsko znanje i didaktičku kompetentnost u oblasti koju predaju (Malešević-Adamović, \& Đurić, 
2011); sposobnost prenošenja znanja, poučavanja (Kostović, 2008); komunikacione veštine, dostupnost i empatiju, neophodnu za studentska pitanja i dileme, a u cilju izgradnje pozitivnih međusobnih odnosa, koji su se pokazali kao krucijalni u motivaciji i podršci studentima (Rubie Davis, 2007); i stručnost u ocenjivanju kroz praćenje i blagovremeno davanje povratnih informacija o njihovom učinku, kako bi dostigli neophodan nivo za polaganje ispita (OECD, 2005).

Uvidom u dosadašnja teorijska i empirijska istraživanja, kao i karakteristike nastavnika koje su u funkciji razvoja kvaliteta nastavnog procesa, pa i same evalucije, možemo izdvojiti sledeće dimenzije kao najznačajnije za naše istraživanje. Planiranje, koje se odnosi se na proces prethodnog dizajniranja nastavnog sadržaja, sa ciljem podsticanja autonomnog i aktivnog učenja (Lukas, Santiago, Etxeberria, \& Lizasoain, 2014). Sledeća dimenzija je nastava kao interakcijsko-komunikacijski odnos nastavnika i studenta. Ona podrazumeva primenu odgovarajućih metodoloških strategija i didaktičkih sredstava koji su potrebni i neophodni za određene predmete sa ciljem razvijanja kompetencija studenata. Takođe se odnosi na motivaciju studenata i prikazivanje entuzijazma od strane nastavnika za postizanje očekivanih rezultata (Lukas i dr., 2014). Treća dimenzija evaluacije nastavnog procesa bio bi rezultat koji se odnosi na sve aspekte koji sadrže rezultat učenja. Tu se podrazumevaju: dostizanje formativnih ciljeva, odgovarajući nivo kompetencija definisanih na početku i zadovoljstvo načinom predavanja (Lukas i dr., 2014).

\section{METODOLOGIJA}

\section{Cilj i zadaci istraživanja}

Cilj ovog rada je uvid u faktore koji utiču na studentsku procenu kvaliteta nastavnog procesa univerzitetskih nastavnika. U skladu sa ciljem istraživanja, postavljeni su sledeći istraživački zadaci:

1) Utvrditi da li akademski uspeh ispitanika utiče na procenu kvaliteta nastavnog proseca univerzitetskih nastavnika.

2) Ispitati da li pol diferencira ispitanike u proceni kvaliteta nastavnog procesa univerzitetskih nastavnika. 


\section{Hipoteze istraživanja}

Na osnovu cilja istraživanja, postavljene su sledeće hipoteze:

$\mathrm{H}_{0^{-}}$pretpostavljamo da određeni faktori utiču na studentsku procenu različitih dimenzija evaluacije nastavnog procesa univerzitetskih nastavnika.

$\mathrm{H}_{1}$ - pretpostavljamo da akademski uspeh ostvaruje pozitivnu korelaciju u odnosu na procenu kvaliteta nastavnog procesa univerzitetskih nastavnika.

$\mathrm{H}_{2}$ - pretpostavljamo da postoji pozitivna povezanost između pola ispitanika i procene kvaliteta nastavnog procesa univerzitetskih nastavnika.

\section{Uzorak i procedura istraživanja}

U istraživanju je učestvovalo 200 ispitanika $(\mathrm{N}=200)$, od čega je bilo 53 (26\%) osobe muškog pola (Grafik 1). Ispitanici su bili studenti treće (198 ispitanika) i četvrte godine ( 2 ispitanika), Filozofskog fakulteta u Novom Sadu sa odseka za psihologiju (57), pedagogiju (55), istoriju (34), anglistiku (25), sociologiju (17), slavistiku (7), i slovakistiku (5). Učesnici su informisani o ciljevima istraživanja i garantovana im je anonimnost podataka. Popunjavanje upitnika je u proseku trajalo 10 minuta, a svi ispitanici su učestvovali dobrovoljno. Istraživanje je sprovedeno u letnjem semestru školske 2016/17.godine.

Grafik 1 Prikaz uzorka u odnosu na pol ispitanika

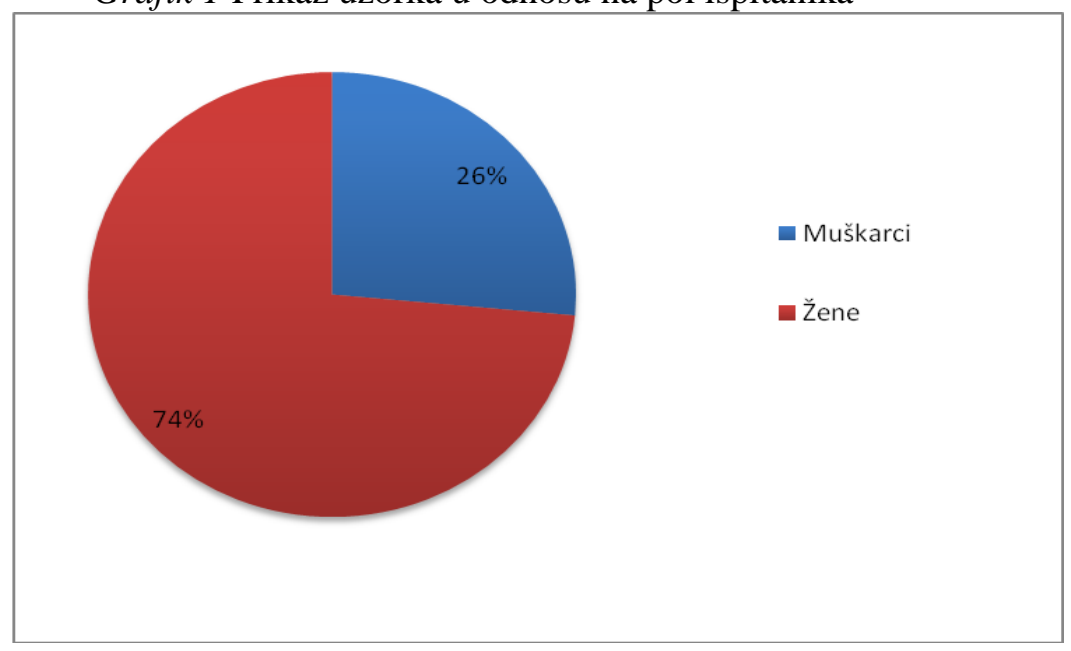




\section{Instrument}

Uzimajući u obzir sve aspekte evaluacije kao i cilj našeg istraživanja, opredelili smo se za instrument Evaluacije nastavnika $\mathrm{u}$ izvođenju nastave (Evaluation of Teaching Performance (CEID)), koji je konstruisan na odseku za psihologiju Universidad Miguel Hernández u Španiji (Moreno Murcia-Torregrosa, \& Belando Pedreno, 2015), za čiju upotrebu smo dobili saglasnost.

Primenjen upitnik sastoji se iz dva dela. Prvi deo upitnika je konstruisan za potrebe ovog istraživanja i sadrži pitanja o polu i godinama ispitanika, godini studija, prosečnoj oceni u prethodnoj godini studija i studijskoj grupi kojoj ispitanici pripadaju. Drugi deo upitnika se odnosi na studentsku percepciju kvaliteta nastavnog procesa na fakultetu.

Instrument se sastoji iz 28 tvrdnji uz petostepeni Likertov format (od 1 uopšte se ne slažem do $5-\mathrm{u}$ potpunosti se slažem). Tvrdnje su grupisane u tri faktora, odnosno dimenzije. Prvi faktor je planiranje nastavnog procesa, sa četiri tvrdnje. Primer stavke je „Profesor/ka pruža jasne informacije o metodama rada, sadržaju, ciljevima, literaturi i zadacima svog predmeta“. Sledeći ispitan faktor je nastava sa sedamnaest tvrdnji (npr. Profesor/ka prezentuje sadržaje jasno, u logičnim okvirima, ukazujući na važne aspekte). Treća dimenzija su rezultati nastavnog procesa, sa sedam stavki. Primer stavke je Profesor/ka primenjuje kriterijume za procenu aktivnosti predviđenu nastavnim planom i programom za taj predmet.

Validacija upitnika je rađena uz pomoć ajtem analize i faktorske analize. Interna konzistentnost skale je dobra, a na pouzdanost skale ukazuje Kronbahova alfa koja je 0.95 . Vrednost h1 koeficijenta je 0.40 , što znači da je upitnik homogen, odnosno da ima jedan predmet merenja. Pored toga, scree plot ukazuje da je u našem istraživanju reč o jednofaktorskom rešenju (Grafik 2). 
Grafik 2 Prikaz scree plota - jednofaktorsko rešenje

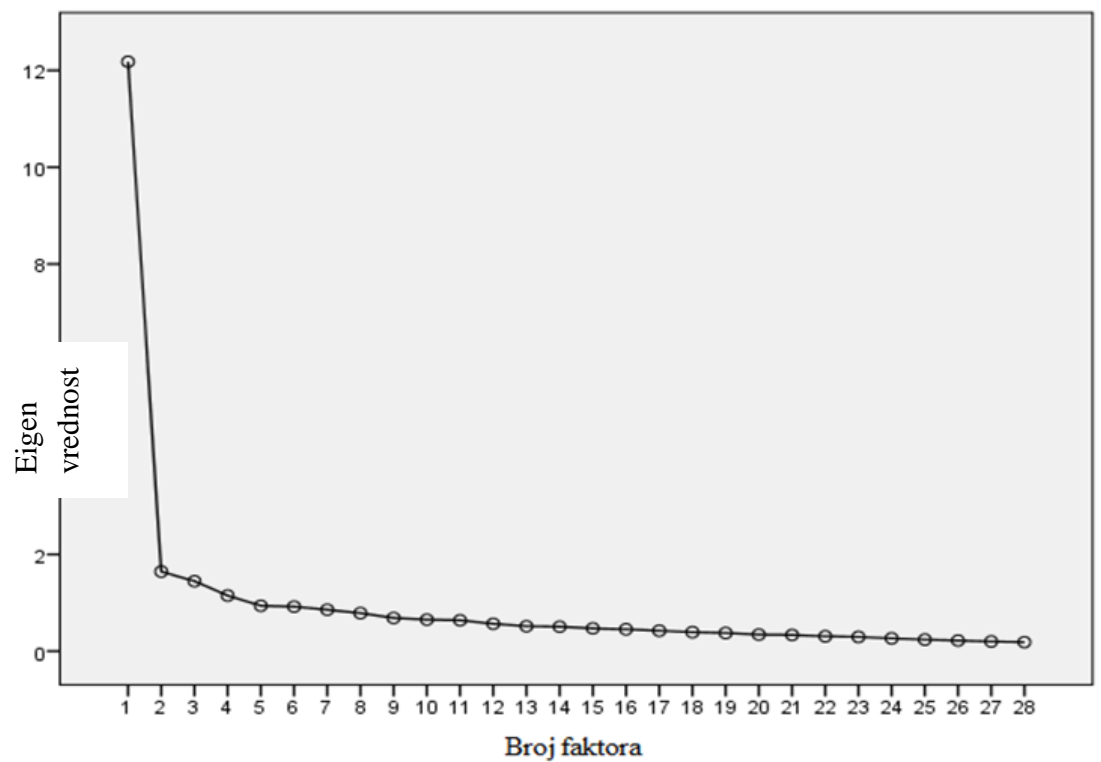

I na osnovu faktorske analize, takođe možemo da zaključimo da upitnik ima jedan faktor (objašnjava 41.90\% latentne varijable). Nakon pregleda zasićenja stavki možemo zaključiti da je opravdano izuzeti stavku 'Profesor/ka predaje minimalni sadržaj svog predmeta prilagođen znanju studenata" s obzirom da je zasićenje niže od 0.32 .

Analiza podataka je rađena u programskom paketu SPSS 22.0, a pored deskriptivne statistike, korišćen je Scheffe test, T test i Pirsonove korelacije.

\section{REZULTATI I DISKUSIJA}

Osnovni rezultat ovog istraživanja na osnovu faktorske analize i Scree plota ukazuje na to da je reč o jednofaktorskom rešenju upitnika kada su naši ispitanici bili u pitanju. Deskriptivnom statistikom za stavke korišćenog upitnika dobijeno je da je prosečna težina stavki upitnika 3.46 (minimalna 3.02. maksimalna 4.28). Minimalnu težinu ima stavka 'Profesor/ka povezuje sadržaje iz učionice sa sadržajima u praksi" dok maksimalnu težinu ima stavka "Profesor/ka poseduje dovoljno znanja o sadržaju predmeta".

Iako je primenjeni upitnik sačinjen od 28 ajtema i sadrži tri faktora, naš rezultat ukazuje na jedan faktor kada je studentska evaluacija nastavnog procesa $\mathrm{u}$ pitanju. Ispitani studenti nastavu posmatraju holistički, bez diferenciranja na 
dimenzije koje postoje u upitniku. Ovakav rezultat može biti posledica velikog broja ispitanika sa različitih studijskih grupa koji su vrednovali veliki broj nastavnika, a imanentne su im različite karakteristike nastavnog procesa. Takođe kulturološke razlike između studenata $u$ različitim državama utiču na razlike $u$ percepciji i shvatanju bitnih činilaca koji čine nastavni proces. "Halo efekat", prva impresija o osobi, se do sada pokazala kao značajan faktor varijacija kada je tema evaluacije nastavnika (Apodaca, \& Grad, 2005; Spooren, \& Mortelmans, 2006) u pitanju. "Halo efekat" koji studenti imaju prema svojim nastavnicima, može da dovede i do netačne interpretacije rezultata evaluacije (Spooren, 2010), odnosno da studenti procenjuju ličnost svojih nastavnika, a ne sam nastavni proces i njegov kvalitet. Ovo može biti i objašnjenje našeg jednofaktorskog rešenja, jer se pokazalo da studenti ne prave jasnu distinkciju između pripreme nastavnika, same nastave i krajnjeg rezultata pri evaluaciji univerzitetskih nastavnika kod nas.

Dobijeni rezultati ukazuju da akademski uspeh studenata ne ostvaruje značajnu pozitivnu korelaciju sa percipiranjem kvaliteta nastavnog procesa (Tabela 1). Prosek ispitanika na studijama je od 6.84 do 10.00. Srednja vrednost za prosek na studijama je 8.34 .

Tabela 1 Prikaz Pirsonovih korelacija za akademski uspeh na studijama i procenu kvaliteta nastavnog procesa

\begin{tabular}{lcc}
\hline & $\begin{array}{c}\text { Procena kvaliteta nastavnog } \\
\text { procesa }\end{array}$ & Prosečna ocena \\
\hline $\begin{array}{l}\text { Procena kvaliteta nastavnog } \\
\text { procesa }\end{array}$ & 1.000 & -.067 \\
Prosečna ocena & -.067 & 1.000 \\
\hline
\end{tabular}

Dosadašnja istraživanja su pokazala da je akademski uspeh i ocena na ispitu u pozitivnoj korelaciji sa evaluacijom nastavnika (Feldman, 2007; Benton-Duchon, \& Pallett, 2011), tačnije, studenti sa najvišim ocenama su najbolje ocenjivali svoje nastavnike (Cohen, 1981). Naši rezultati pokazuju da akademski uspeh nije determinanta pozitivne procene nastavnog procesa. Interesantno je da ispitanici nisu prepoznali i izdvojili dimenziju "rezultat nastavnog procesa". S obzirom da su naši ispitanici bili treća godina studija (samo dvoje četvrta godina), moguće je da studenti sa viših godina studija, bez obzira na postignute rezultate, usled veće zrelosti i upućenosti u program studija, ujednačenije ocenjuju svoje nastavnike nezavisno od akademskog uspeha (Wachtel, 1998).

Dalje, rezultati našeg istraživanja na osnovu t testa pokazuju da postoji značajna razlika u evaluaciji nastavnog procesa univerzitetskih nastavnika od strane 
studenata u odnosu na pol ispitanika (Tabela 2). Muškarci imaju pozitivniji odnos prema univerzitetskim nastavnicima kada je nastavni proces u pitanju.

Tabela 2 Prikaz kvaliteta nastavnog procesa u odnosu na pol ispitanika

\begin{tabular}{ccc}
\hline $\mathrm{t}$ test & $\mathrm{df}$ & Značajnost \\
\hline 4.345 & 180 & $\mathbf{0 . 0 0 1}$ \\
\hline
\end{tabular}

Na Grafiku 3 se mogu videti deskriptivne vrednosti za procenu kvaliteta nastavnog procesa u odnosu na pol ispitanika.

Grafik 3 Prikaz procene kvaliteta nastavnog procesa u odnosu na pol ispitanika

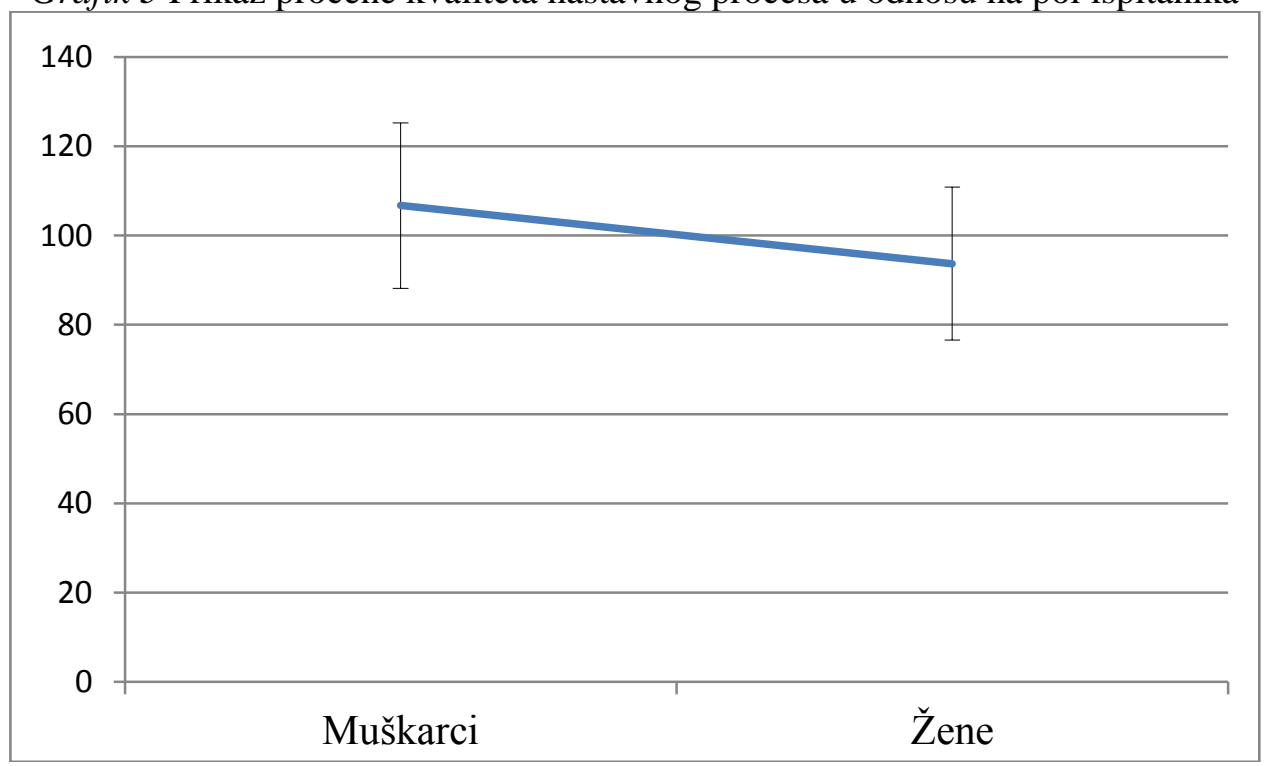

Ovaj rezultat je u skladu sa ranijim istraživanjima (Centra, \& Gaubatz, 2000; Feldman, 2007), koja pokazuju da postoji razlika u polovima kada je procena kvaliteta nastavnog procesa univerzitetskih nastavnika $\mathrm{u}$ pitanju. $\mathrm{U}$ naredna istraživanja bi trebalo uključiti i pol nastavnika, jer se pokazalo da postoji povezanost između polova studenata i nastavnika (Centra, \& Gaubatz, 2000), odnosno da studentkinje preferiraju nastavnice, a studenti nastavnike muškog pola. 


\section{PEDAGOŠKE IMPLIKACIJE I ZAKLJUČCI}

Generalni zaključak ovog rada je da su se studenti, iako su od početka studiranja upućeni u ulogu evaluacije, pokazali kao nedovoljno kvalifikovani da procenjuju ulogu nastavnika u nastavnom procesu. To je ujedno i ograničavajući faktor ovog istraživanja jer rezultat o jednofaktorskom rešenju upitnika, pokazuje da studenti procenjuju ličnost nastavnika i nastavni stil (Centra, \& Gaubatz, 2000), a ne nastavni proces koji se ispituje ovim instrumentom. Kako bi studenti postali kompetentniji za procenu rada svojih nastavnika neophodno je da se sa njima radi na podizanju svesti o značaju različitih dimenzija nastavnog procesa i razvoju kritičkog mišljenja, što bi smanjilo uticaj procene ličnosti nastavnika na procenu njegovog rada.

Da bi se povećala sigurnost $\mathrm{u}$ kvalitet evaluacije nastavnog procesa, neophodno je da se uključe i kvalifikovani profesionalci kao izvor informacija sveobuhvatne procene (Berk, 2013). Studentska evaluacija je neophodna, ali se pokazala kao jednostrana. Evaluacija nastavnog procesa univerzitetskih nastavnika predstavlja multidimenzionalni konstrukt, koji ne može da bude meren samo jednim indikatorom (Gursoy, \& Umbreit, 2005). Ona treba da predstavlja složen sistem principa, tehnika i oblika vrednovanja, koji bi omogućio višedimenzionalno praćenje i procenu određenih indikatora kvaliteta vaspitno-obrazovnog procesa (Đermanov, 2005). Procena objektivnih karakteristika uloge nastavnika je filtrirana kroz studentsko viđenje različitih činilaca i tako postaje subjektivna. Pored dodatne evaluacije od strane stručnih lica, kao pokazatelj kvaliteta nastavnog procesa, mogli bi da se uključe i samovrednovanje, evaluacija od strane kolega, portfolio nastavnika za određeni predmet i rezultati ispita.

Ovo istraživanje je rasvetlilo neke značajne momente $u$ evaluaciji nastavnog procesa univerzitetskih nastavnika, ali je i podstrek razvoju visokoškolske didaktike, jer činjenica je da znanje i stručnost u određenoj oblasti ne podrazumevaju nužno i uspešno poučavanje toga. Kvalitet nastave sadrži ono što je proces nastave, kao i ono što predstavlja rezultat.

Pored razvoja kompetencija koje se odnose na naučno-istraživački rad, neophodno je i usavršavanje pedagoških i andragoških veština nastavnika, jer je samo to siguran put ka većem zadovoljstvu studenata, koje će voditi pozitivnijoj evaluaciji nastavnog procesa. 
Borka Malčić, Nataša Tančić, Svetlana Kostović

DIMENSIONS OF THE TEACHERS' ROLE IN HIGHER EDUCATION FROM THE STUDENTS' PERSPECTIVE

\section{Summary}

In the modern society throughout the world, universities have become a part of industry, whose priorities are student satisfaction and competition for better ranking among a variety of available faculties and student programmes in our country and abroad. In the learning paradigm, the teacher's role has been changed. Teachers have become collaborators, partners and mentors in conceptualizing teaching activities mainly based on students as major actors, who express their subject position in the teaching process through student evaluation of teaching.

The aim of this paper was students' evaluation of teaching performance in higher education, evaluation of the teaching process in regard to gender differences of the respondents and evaluation of the teaching process in correlation with the academic achievement of the respondents.

The respondents were the third-year students $(\mathrm{N}=200)$ enrolled at seven study programmes at the Faculty of Philosophy in Novi Sad, 53 of whom were male. The respondents have filled in a two part questionnaire. The first part of the questionnaire refers to the student's gender, study programmes and the student's achievement data from the previous year, while the second part consists of the Evaluation of Teaching Performance questionnaire (CEID, Moreno Murcia-Torregrosa \& Belando Pedreno, 2015). The instrument items are grouped into 3 factors. The first refers to the planning phase, the second to the teaching process phase, while the third refers to the result phase of the teaching process. The analysis data has been carried out in SPSS 22.0 programme package, and besides the descriptive statistics, Sheffe's test, T-test and Pearson Correlation have also been used.

The analysis data have shown that the questionnaire used for our respondents had one factor. Student achievement does not significantly make a positive correlation with the perception of teaching quality performance. However, the data have shown statistically significant difference in the student evaluation of teaching performance of university teachers in regard to student gender.

Students' evaluation is necessary, but not enough for a multidimensional construct in the evaluation of teaching performance in higher education. Although student evaluation of teachers should have an important role in the evaluation of teaching performance, at the same time it should be only a part of teaching and teacher quality data. It's obvious that an estimation of objective characteristics of the teaching process has been filtered through their perceptual system and other factors involved. Therefore, the modern pedagogical evaluation concept must also include various types of evaluation, while the teacher's self-evaluation must be its priority.

Key words: students, university, evaluation, teaching process, teacher's role. 


\section{LITERATURA}

Apodaca, P., \& Grad, H. (2005). The dimensionality of student ratings of teaching: Integration of uni- and multidimensional models. Studies in Higher Education, 30, 723-748doi:10.1080/03075070500340101.

Benton, S. L., Duchon, D., \& Pallett, W. H., (2011). Validity of student selfreported ratings of instruction. Assessment \& Evaluation in Higher Education. http://dx.doi.org/10.1080/02602938.2011.636799.

Berk, R. A. (2005). Survey of 12 strategies to measure teaching effectiveness. International Journal of Teaching and Learning in Higher Education, 17(1), 48-62.

Berk, R. A. (2013). Top five flashpoints in the assessment of teaching effectiveness. Medical Teacher, 35, 15-26.

Centra, J. A., \& Gaubatz, N. B. (2000). Is there gender bias in student evaluations of teaching? The Journal of Higher Education, 71, 17-33.

Cohen, P. A. (1981). Student ratings of instruction and student achievement: A metaanalysis of multisection validity studies. Review of Educational Research, 51, 281-309. doi:10.3102/00346543051003281.

Đermanov, J. (2003). Promene u strukturi i funkcijama vrednovanja vaspitnoobrazovne delatnosti - od selektivne ka razvojnoj funkciji. Pedagoška stvarnost, 18, 32-43.

Đermanov, J. (2005). Inovativne forme evaluacije vaspitno-obrazovnog procesa $\mathrm{u}$ reformisanoj školi. U: Kamenov, E. (ured.) (2005). Reforma školskog sistema u uslovima tranzicije. Novi Sad: Filozofski fakultet. 57-67.

Đukić, M. (2002a). Studentsko ocenjivanje nastave i nastavnika (pro et contra). Zbornik odseka za pedagogiju, 17, 21-30.

Đukić, M. (2002b). Savremene reforme vrednovanja viskoškolske nastave. U: Kamenov, E. (ured.) (2002). Strategija razvoja sistema vaspitanja i obrazovanja u uslovima tranzicije. Rezultati komparativnih i prekseoloških proučavanja. Novi Sad: Filozofski fakultet. 223-246.

Đukić, M. (2006/2007). Konstruktivistička evaluacija nastave: didaktičke implikacije. Zbornik odseka za pedagogiju, 20/21, 107-118.

Đukić, M. (2010). Nova paradigma univerzitetske nastave kao izraz pedagoške reforme

visokog obrazovanja. Socioška luča IV/I, str. 135-145.

Feldman, K. A. (1976). The superior college teacher from the students' view. Research in

Higher Education, 5(3), 243-288. 
Feldman, K. A. (1988). Effective college teaching from the students and faculty views: matched or mismatched priorities? Research in Higher Education, 28 (4), 291-329.

Feldman, K. A. (2007). Identifying exemplary teachers and teaching: Evidence from student ratings. In R. P. Perry \& J. C. Smart (Eds.), The Scholarship of teaching and learning in higher education: An evidence-based perspective (pp. 93-129). Dordrecht, The Netherlands: Springer.

Gursoy, D., \& Umbreit, W. T. (2005). Exploring Students`Evaluations of Teaching Effectivness: What Factors are Important? Journal of Hospitality \& Tourism Research, 1 (29), 91-109. doi:10.1177/1096348004268197

Helgesen, Ø., \& Nesset, E. (2007). What accounts for students' loyalty? Some field study evidence. International Journal of Educational Management, 21(2), 126-143.

Jackson, D. L., Teal, C. R., Raines, S. J., \& Nansel, T. R. (1999). The dimensions of students' perceptions of teaching effectiveness. Educational and Psychological Measurement, 59(4), 580-596.

Johnston, M., \& Reid, D.J. (1999). Improving teaching in higher education, Educational Studies, 25(3), 269-281.

Kostović, S. (2008). Pigmalion u razredu. Novi Sad: Filozofski fakultet.

Kuzmanović, M. Savić, G. Gušavac, B.A. Makajić-Nikolić, D., \& Panić, B. (2013). A Conjoint-based approach to student evaluations of teaching performance. Expert Systems with Applications, 40(10), 4083-4089. doi:10.1016/j.esw.2013.01.039

Lukas, J. F., Santiago, K., Etxeberria, J., \& Lizasoain, L. (2014). Adapting to the European Higher Education Area a questionnaire on student opinion about the teaching of lecturers. Revista Electrónica de Investigación y Evaluación Edu-cativa, 20(1). doi:10.7203/relieve.20.1.3812

Malešević, D., Adamović, Z., \& Đurić, Z. (2011). The influence of competences of a teacher on the quality of professional education. Technics Technologies Education Management-TTEM, 6(4), 1100-1109.

Marsh, H. W. (2007). Students' evaluations of university teaching: Dimensionality, reliability, validity, potential biases and usefulness. In R. P. Perry \& J. C. Smart (Eds.), The scholarship of teaching and learning in higher education: An evidencebased perspective (pp. 319-384). New York, NY: Springer.

Moreno-Murcia, J.A.-Torregrosa, Y.S., \& Belando Pedreno, N. (2015). Questionnaire evaluating teaching competencies in the university 
environment. Evaluation of teaching competencies in the university. New approaches in Educational research, 4(1), 54-61.

OECD (2005). Teachers matter: Attracting, developing and retaining effective teachers. Paris: OECD.

Rubie-Davis, C. M. (2007). Classroom interactions: Exploring the practices of highand low-expectation teachers. British Journal of Educational Psychology, 77, 289-306.

Spooren, P. (2010). On the credibility of the judge. A cross-classified multilevel analysis on students` evaluation of teaching. Studies in Educational Evaluation, 36, 121-131. doi: 10.1016/j.stueduc.2011.02.001.

Spooren, P., \& Mortelmans, D. (2006). Teacher professionalism and student evaluation of teaching: Will better teachers receive higher ratings and will better students give higher ratings? Educational Studies, 32, 201-214. doi:10.1080/03055690600631101.

Sporn, B. (2003). Management in higher education: Current trends and future perspectives in European colleges and universities. In R. Begg (Ed.), The Dialogue between Higher Education Research and Practice (pp. 97-107). New York: Kluwer Academic Publisher.

Wachtel, H. K. (1998). Student evaluation of college teaching effectiveness: A brief review. Assessment and Evaluation in Higher Education, 23, 191-210 doi:10.1080/0260293980230207. 
